\title{
Anatomical investigations of Nonea dumanii (Boraginaceae)
}

Yeter YEŞIL

\begin{abstract}
Nonea Medik. species are represented worldwide by about 35 species and represented by 23 species in Turkey. Nonea species are commonly known as Sormuk otu and some species use as folk medicine; aerial parts prepared as porridge are used for wound healing and internally for stomachache in Turkey.

In this study stem and leaf anatomy of the endemic Nonea dumanii Bilgili \& Selvi species (Boraginaceae) was investigated. In the cross section of stem, cortex has 2-3 layers collenchymatic cells and multilayered parenchymatic cells. Epidermis contains glandular and eglandular trichomes on stem and leaf. Xylem is
\end{abstract}

composed of sclerenchymatic cells and tracheary elements in vascular bundles. The pith is composed of parenchymatical cells.

Stomata are anomocytic and amphistomatic in leaves. The sizes of stomata in abaxial surface are bigger than the sizes of stomata in adaxial surface, also stomata index of abaxial surface is bigger than in adaxial surface. Minor bundles are surrounded by one layered parenchymatic sheat in leaf. Palisade tissue is existing on both side of leaf (isobilateral). Spongy tissue is reduced to a thin layer in the center of the mesophyll.

Key Words: Nonea; Boraginaceae; Boragineae; dumanii; anatomy; Antalya
Yeter Yeşil

Istanbul University, Faculty of Pharmacy, Department of Pharmaceutical Botany

Corresponding Author:

Yeter Yeşil

e-mail:yeteryesil@yahoo.com

Submitted / Gönderilme: 22.05.2017 Revised / Düzeltme: 05.07.2017 Accepted / Kabul: $\quad$ 07.07.2017

How to cite this article: Yeşil Y. Anatomical investigations of Nonea dumanii (Boraginaceae). Marmara Pharm J 2017; 21 (4): 804-809

\section{Introduction}

Nonea Medik. (Boraginaceae tribe Boragineae) includes some 35 species characterized by accrescent fruiting calyx, corolla with hairy appendages at the throat and presence of glandular hairs on leaves, stems and/or cymes. With respect to the phylogenetically close genus Pulmonaria L., it shows a broader diversity of forms and interspecific variation in habit, lifeform, flowerand fruit morphology, as well as in taxonomically important microcharacters such as pollen and stigma [1]. The traditional taxonomy of this group has long followed Candolle's [2] treatment with three sections mainly based on nutlet form and anther position in the corolla tube. However, molecular phylogenetic analyses have shown that these sections are not natural lineages, and that the genus is monophyletic only when the traditionally recognized genus Elizaldia Willk. is included in Nonea and the species Nonea obtusifolia (Willd.) DC. is instead segregated in the monotypic genus Melanortocarya Selvi et al. [3]. The distribution of the genus ranges from central Asia to the Atlantic area in the Iberian Peninsula and Morocco, with a main centre of diversity in the Pontic-Caucasian area and in the highlands of the Irano-Turanian region and Anatolia. 
Turkey is the richest country with respect to Nonea taxa, with approximately 23 species, eight of which are endemic to Anatolia [4-7].

Nonea species are commonly known as Sormuk otu and some species uses as folk medicine; aerial parts prepared as porridge are used for wound healing and internally for stomachache in Turkey [8-11].

Nonea dumanii is endemic to the mountains of the western Taurus in south Turkey. Karyological observations and analysis of ITS1 DNA sequences showed that the species has phylogenetic affinity to $N$. monticola as well as to $N$. anchusoides from Turkey. Nonea dumanii is morphologically distinct from these species in characters of the well-developed indumentum, dull pink to pale red flower and larger fruit. Also it is differing by its ascending stem [6] (Figure 1).

Selvi and Bigazzi [12] analysed and compared the leaf anatomical charactericstics of 54 taxa belonging to 14 Boraginaceae genera, it includes 14 taxa of Nonea. They used the description terminology of Metcalf and Chalk's [13] study about Boraginaceae for typification of trichomes, and they observed 4 trichome types on the leaves of Nonea species.

\section{Results and Discussion}

In this study, anatomical properties of stem and leaf of Nonea dumanii were examined.

\subsection{Stem}

Epidermis is single layered and breadth is ranging from 10.58 to $21.28 \mu \mathrm{m}$, length is ranging from 11.39 to $28.98 \mu \mathrm{m}$. There are glandular and eglandular trichomes on the epidermis. They are unicellular or multicellular. Long glandular hairs consisting of three or more stalk cells and an elongated secretory cell. Stem has small 4-6 wings, collenchyma is especially located with 4-5 layered cell in the wings and is 1-3 layered in other parts of stem. Cortex has 2-3 layers collenchymatical cells and multilayered parenchymatical cells. Parenchyma cells are 37.89-88.03 $\mu \mathrm{m}$ x 71.75-24.96 $\mu \mathrm{m}$. Endodermis is located above the phloem. Cambium is indistinguishable. Xylem is composed of sclerenchymatic cell and tracheary elements in stem. Diameter of trachea cells are $26.60-14.71 \mu \mathrm{m}$. The pith consists of large and cylindrical parenchymatic cells, Diameter of trachea cells are 113.73 $28.15 \mu \mathrm{m}$ (Figure 2) (Table 1).
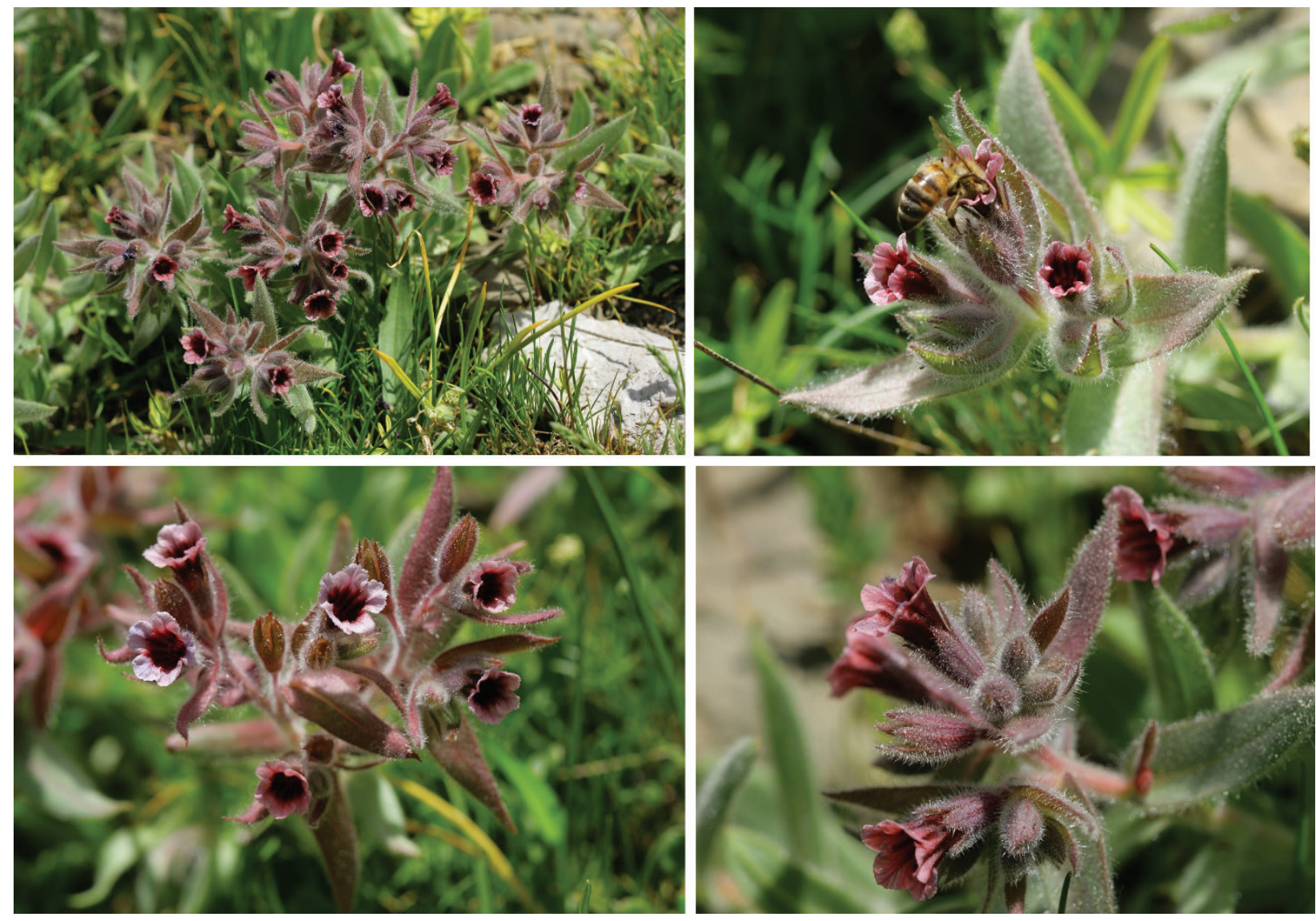

Figure 1. The general view of Nonea dumanii Bilgili \& Selvi, 18.05.2015, Alanya (Antalya). 

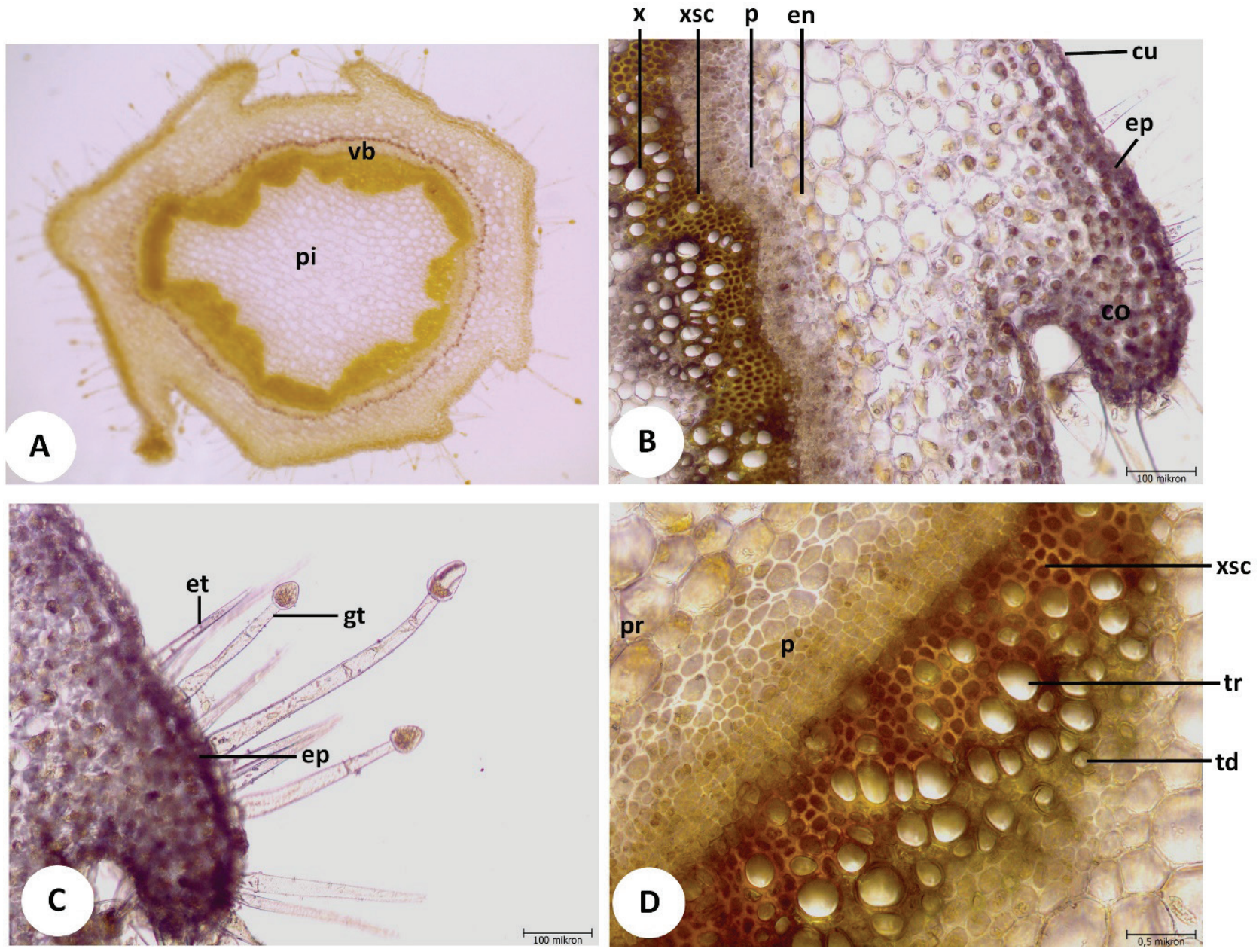

Figure 2. The cross sections of stem of N. dumanii; A general view, B cortex and vascular bundles, C trichomes, D vascular bundles; ep epidermis, en endodermis, co collenchyma, cu cuticula, eg e glandular trichome, gt glandular trichome, p phloem, pi pith, pr parenchyma, tr trache, td tracheid, x xylem xsc xylem sclerenchyma, vb vascular bundle.

Table 1. Anatomical measurements of Nonea dumanii

\begin{tabular}{lll}
\hline Plant part & $\begin{array}{l}\text { Breadth }(\mu \mathrm{m}) \\
\text { Mean } \pm \text { SE }\end{array}$ & $\begin{array}{l}\text { Length }(\mu \mathrm{m}) \\
\text { Mean } \pm \text { SE }\end{array}$ \\
\hline Stem Epidermis cells & $21.28 \pm 10.58$ & $28.98 \pm 11.39$ \\
Collenchyma cells & $26.11 \pm 14.46$ & $26.94 \pm 15.44$ \\
Parenchyma cells & $71.75 \pm 24.96$ & $88.03 \pm 37.89$ \\
Diameter of trachea & $26.60 \pm 14.71$ & \\
Diameter of pith ray cells & $113.73 \pm 28.15$ & \\
Leaf Adaxial epidermis cells & $44.75 \pm 15.44$ & $82.84 \pm 18.09$ \\
Abaxial epidermis cells & $55.99 \pm 19.39$ & $91.50 \pm 47.22$ \\
Palisade parenchyma cells & $13.45 \pm 11.70$ & $65.94 \pm 35.61$ \\
Spongy parenchyma cells & $38.94 \pm 24.34$ & $34.33 \pm 17.61$ \\
\hline
\end{tabular}




\subsection{Leaf}

Leaf surfaces of the species are more or less densely covered by different types of uniseriate trichomes forming an indumentum of variable texture and density. Selvi and Bigazzi [12] explained the leaf anatomical characteristics of 14 taxa of Nonea. According to this study the trichome types of N. dumanii are similar to N. pulla, N. lutea and N. caspica species with long glandular hairs consisting of three and more stalk cells and a longated sectetory cell (Figure $3 \mathrm{C}-\mathrm{D}$ ).

On the cross section, epidermal cells of both surfaces are arranged in a single layer. In terms of size, the abaxial epidermal cells are usually slightly larger than those of the adaxial epidermis. Outer walls of epidermal cells especially on the adaxial side, are impregnated with a layer of cutin, the thickness of the outer cell wall range from about $1 \mu \mathrm{m}$. Leaves are amphiphstomatic, in the taxa with palisade cells on both surfaces, the spongy tissue is reduced to a thin layer in the center of the mesophyll. The leaf showing incipient isobilateral symetry with adaxial and abaxial clorenchyma with wide intercellular spaces (Table 1, Figure 3 B).

Veins are typically bicollateral, with the xylem located adaxially and strands of phloem abaxially (Figure $3 \mathrm{~A}$ ). Mechanical tissue of collenchymatic nature is associated to the major veins, and minor ones are enclosed within a parenchymatous single-layered bundle sheath (Figure 3 B).

Leaves have anomocytic stomata oval in shape and variable in size (Figure $3 \mathrm{C}-\mathrm{D}$ ), and the distribution of the stomata is fairly homogeneous on both surfaces.

The mean number of stomata per $1 \mathrm{~mm}^{2}$ range from 52 to 67 and 85- 98 on the upper and lower surfaces, respectively. The adaxial density is lower than the abaxial one.

Abaxial stomatal length, which ranges from 46.46 to 33.41 $\mu \mathrm{m}$, and density are inversely correlated in a highly significant way (Table 2).
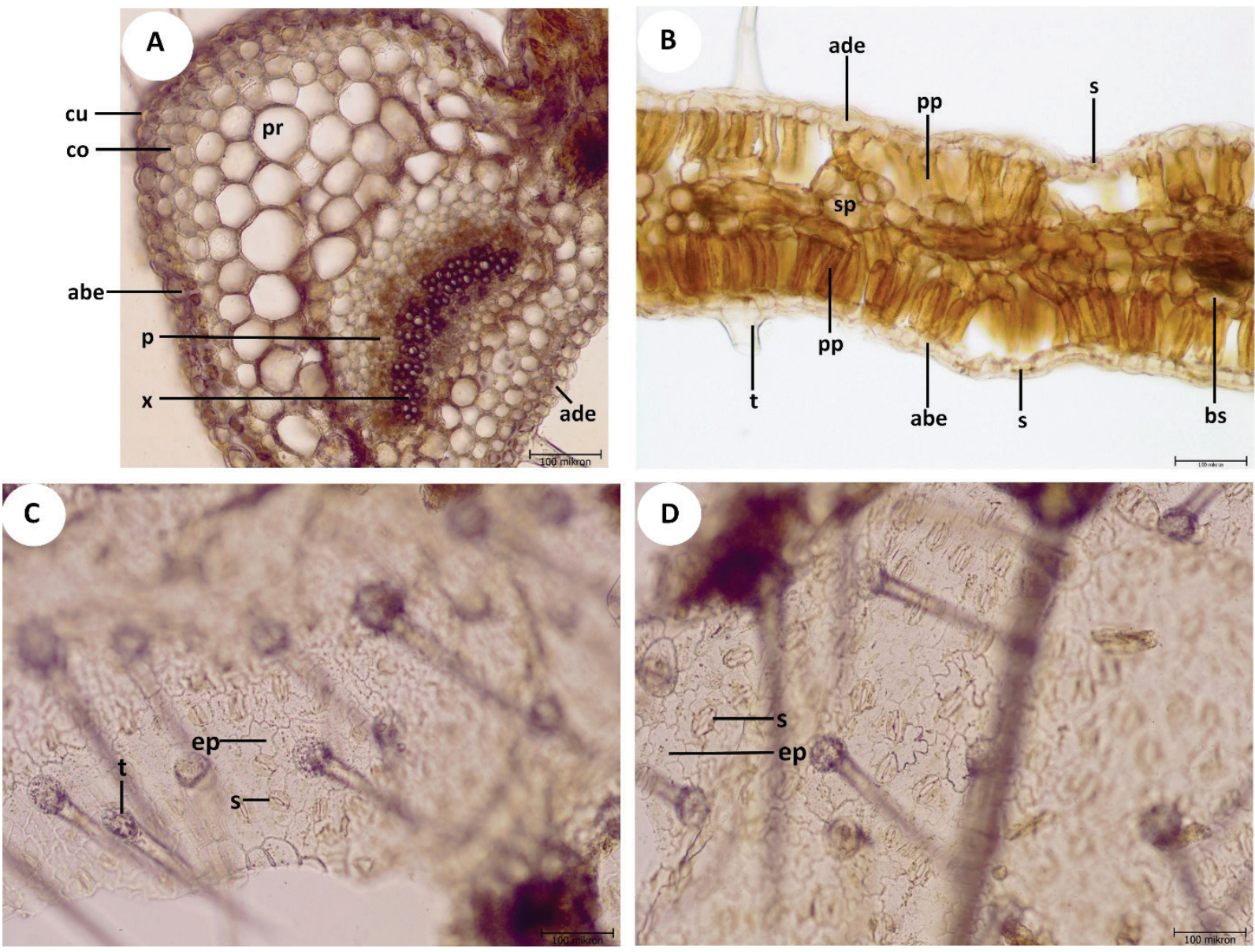

Figure 3. The cross and surface sections of leaves of $N$. dumanii; A the main vein, B intervascular part of leaf (mesophyll), C adaxial surface of leaf, D abaxial surface of leaf; abe abaxial epidermis, ade adaxial epidermis, bs bundle sheath, ep epidermis, co collenchyma, cu cuticula, $\mathrm{p}$ phloem, pp palisade parenchyma, pr parenchyma, $\mathrm{t}$ trichome, s stoma, sp spongy parenchyma, $\mathrm{x} x y l e m$. 
Table 2. Trichome and stoma features on the adaxial and abaxial epidermis of N. dumanii

\begin{tabular}{lll}
\hline & Adaxial surface of leaf & Abaxial surface of leaf \\
\hline Number of eglandular trichomes $\left(\mathbf{1} \mathbf{~ m}^{2}\right)$ & 11 & 12 \\
\hline Number of glandular tricomes $\left(\mathbf{1} \mathbf{~ m m}^{2}\right)$ & 5 & 5 \\
\hline Number of stomata $\left(\mathbf{1} \mathbf{~ m m}^{2}\right)$ & $52-67$ & $85-98$ \\
\hline Number of epidermis cells $\left(\mathbf{1} \mathbf{~ m m}^{2}\right)$ & 182 & 251 \\
\hline Stomata length & $40.61 \mu \mathrm{m}-26.78 \mu \mathrm{m}$ & $46.46 \mu \mathrm{m}-33.41 \mu \mathrm{m}$ \\
\hline Stomata width & $31.22 \mu \mathrm{m}-21.24 \mu \mathrm{m}$ & $33.64 \mu \mathrm{m}-25.11 \mu \mathrm{m}$ \\
\hline Stomata index & 26.90 & 28.16 \\
\hline Stomata index rate & 0.955 & \\
\hline
\end{tabular}

\section{Conclusion}

Stem anatomy shows the typical dicotyledonous stem anatomy, presence of well-defined epidermis with cuticle and multicellular stem trichomes, cortex has collenchymatous tissues regularly, Endodermis is distinct as the innermost layer of the cortex. Vascular bundles are conjoint, collateral, endarch, and open and arranged in a ring surrounding pith. The pith is made from thin walled parenchyma cells with distinct intercellular spaces.

Leaf anatomy; an epidermal layer is present on the upper as well as lower surfaces. Photosynthetic tissues are abaxial and adaxial in N. dumanii in leaf cross section. Vascular bundles are collateral. The xylem is present towards the upper epidermis and consists of vessels and xylem parenchyma. Phloem is situated is present towards the lower epidermis. Stomata sizes, stomata index and epidermis cells sizes of abaxial surface in leaf are bigger than the adaxial surface

\section{Material and Method}

The study is based on field, herbarium and literature surveys. Nonea dumani from Antalya (ISTE 113710) were collected and the herbarium specimens of Nonea protected at the ISTE herbaria. Minimum 15 individual specimens were used for anatomical studies of the species. For the anatomical investigation, leaves and stems were firstly submersed in warm water, and then all transverse sections and surficial sections were cut by hand from the middle of leaves and stems using a blade. Samples were investigated in Sartur reagent (a compound reagent of lactic acid, Sudan III, aniline, iodine, potassium iodide, alcohol, and water) [14]. Photographs were taken with Canon Power shot A640 and measurements of stems and leaves were made by program of KAMERAM@.

\section{Acknowledgements}

Research grants from the Scientific Research Projects Department of Istanbul University by project number 41403.

\section{Authorship Statement}

Author contributions: Concept - Y.Y.; Design - Y.Y.; Supervision - Y.Y.; Resource - Y.Y.; Materials - Y.Y.; Data Collection and/or Processing - Y.Y.; Analysis and/or Interpretation - Y.Y.; Literature Search - Y.Y.; Writing - Y.Y.; Critical Reviews - Y.Y.

\section{Conflict of Interest Statement}

The authors declared no conflict of interest.

\section{References}

1. Selvi F, Bigazii M. Chromosome studies in Turkish species of Nonea (Boraginaceae): The role of polyploidy and descending dysploidy in the evolution of the genus. Edinb J Bot 2002; 59: 405-20.

2. Candolle AD. Prodromus systematis naturalis regni vegetabilis, Vol. 10. Masson, Paris. 1846, pp. 37-34.

3. Selvi F, Bigazzi M, Hilger HH, Papini A. Molecular phylogeny, morphology and taxonomic re-circumscription of the generic complex Nonea/Elizaldia/Pulmonaria /Paraskevia (Boraginaceae-Boragineae). Taxon 2006; 55: 907-18.

4. Baytop A. Nonea Medicus. In: Davis PH. (Ed). Flora of Turkey and the East Aegean Islands, Vol 6. Edinburgh University 
Press, Edinburgh Bahçesi ve Flora Araștırmaları Derneği Yayını, Istanbul, Turkey. 1978, pp. 404-415.

5. Selvi F, Bigazzi M. Nonea pallens (Boraginaceae), a new addition to the flora of Turkey. Edinb J Bot 1999; 56: 361-9.

6. Bilgili B, Papini A, Selvi F. Nonea dumanii sp. nov. (Boraginaceae) from the Taurus mountains (South Turkey). Nord J Bot 2012; 30: 546-52.

7. Körüklü ST, Nonea Medicus. L. In: Güner A, Aslan S, Ekim T, Vural M, Babaç MT. (Eds). Türkiye Bitkileri Listesi/ Damarlı Bitkiler. Nezahat Gökyiğit Botanik Bahçesi ve Flora Araştırmaları Derneği Yayını, İstanbul. 2012, pp. 232-234.

8. Baytop T. Türkiye'de Bitkiler ile Tedavi. Sanal Matbaacıllk, İstanbul, Turkey. 1984.

9. Baytop T. Türkçe Bitki Adları Sözlügü. Türk Tarih Kurumu
Basımevi, Ankara, Turkey. 1994.

10. Tuzlacı E. Türkiye Bitkileri Sözlüğü, Alfa Yayınları, İstanbul, Turkey. 2006.

11. Altundağ E, Öztürk M. Ethnomedicinal studies on the plant resources of East Anatolia, Turkey. Procedia Soc Behav Sci 2011; 19: 756-77.

12. Selvi F, Bigazzi M. Leaf surface and anatomy in Boraginaceae tribe Boragineae with respect to ecology and taxonomy. Flora 2001; 196: 269-85.

13. Metcalfe CR, Chalk L. Anatomy of the dicotyledons, Vol 2, $2^{\text {nd }}$ ed. Clarendon, Oxford, England. 1979.

14. Çelebioğlu S, Baytop T. A new reagent for microscopical investigation of plant. Publication of the Institute of Pharmacognosy 1949; 10: 301. 